\title{
Hva mener Legeforeningen?
}

I mars 2013 sendte stortingsrepresentant Jan-Henrik Fredriksen (FrP) et skriftlig spørsmål til helse- og omsorgsministeren (1). I begrunnelsen for spørsmålet henviste han til en fersk vitenskapelig artikkel i Tidsskriftet (2). Fredriksen skrev at «(...) legeforeningen anbefaler bruk av Funksjonell MR og CT» (1). Jeg stusset. Hadde virkelig Legeforeningen anbefalt spesifikke bildeundersøkelser i en artikkel om atlantoaksial rotasjonsfiksasjon? Nei, selvsagt ikke. Men politikeren er sikkert ikke alene om å tro det.

Tidsskrift for Den norske legeforening er, som navnet sier, Legeforeningens tidsskrift. Foreningen eier bladet, alle medlemmer i foreningen får det som en del av medlemskapet, og vi som arbeider i redaksjonen, er ansatt i foreningens sekretariat. Men hvordan er forholdet mellom Legeforeningen og Tidsskriftet? I hver eneste utgave står det følgende på fast plass: «Tidsskriftet redigeres etter redaktørplakaten og alt som publiseres representerer forfatterens synspunkter. Disse samsvarer ikke nødvendigvis med redaksjonens eller Den norske legeforenings offisielle synspunkter med mindre dette kommer særskilt til uttrykk.»

Det er i år 60 år siden norske mediers redaktørplakat kom i stand. Den skal sikre redaktørens uavhengighet overfor eierne (3). Legeforeningen bestemte seg i 1996 for å nedfelle i sine lover at Tidsskriftet skal redigeres etter denne erklæringen: «Redaktøren utøver sin myndighet og sitt ansvar i henhold til redaktørplakaten» (4). Fra 2009 er prinsippene i redaktørplakaten lovfestet gjennom mediefridomslova, men i loven står det eksplisitt at den ikke gjelder medier «(...) som hovudsakleg er retta mot medlemmer eller tilsette i bestemte organisasjonar, foreiningar eller selskap» (5). Det er altså ingen selvfølge at Tidsskriftet redigeres etter redaktørplakaten. Dette er omtalt på denne plass tidligere, men det kan være grunn til å minne om det (6).

Også mange andre medisinske tidsskrifter er eid av en legeforening. Dette gjelder noen av de fremste: $J A M A$, eid av American Medical Association, og The New England Journal of Medicine, eid av Massachusetts Medical Society. I enkelte tidsskrifter (f.eks. JAMA), står det eksplisitt på samme side som lederartiklene at disse uttrykker forfatterens meninger og ikke eierens, dvs. den aktuelle legeforeningen. I andre tidsskrifter, som The New England Journal of Medicine, står liknende informasjon på kolofonsiden. Det samme gjelder Tidsskrift for Den norske legeforening. Vi har valgt å ha en slik tekst sammen med generell informasjon om Tidsskriftet for å få frem at opplysningen gjelder alle typer artikler der meninger og synspunkter kommer frem. De fleste artiklene har et subjektivt meningsinnhold - det gjelder slett ikke bare lederartiklene. Som redaktøren i Annals of Internal Medicine sier det: «Forskning er ikke sannhet, men fortellinger» (7). Sagt på en annen måte: Medisin er debatt (8). Det ville være uhensiktsmessig om hver eneste artikkel i Tidsskriftet skulle ha en påtegning om at innholdet $i$ artikkelen representer forfatternes oppfatninger.

La meg illustrere poenget ved å bruke en parallell fra dagsavisene: Når for eksempel antiislamisten Peder Jensen («Fjordman») får publisert en kronikk i Aftenposten, vil ingen finne på å si at «Schibsted-konsernet mener at...». Slik er det i Tidsskriftet også. Innholdet $i$ artiklene står for forfatternes regning.

Det er i dag ganske opplagt at eieren av et medieforetak ikke kan instruere eller overprøve redaktøren i redaksjonelle spørsmål (3). Legeforeningen er en profesjonell eier av Tidsskriftet, og i mine drøyt 12 år i redaksjonen har foreningen aldri på noe vis forsøkt å påvirke innholdet. Kun på ett sted i Tidsskriftet fremkommer Legeforeningens meninger, nemlig i seksjonen Aktuelt i foreningen, som finnes bakerst $i$ hver utgave. Her står bl.a. en lederartikkel av Legeforeningens president. Den målbærer foreningens offisielle synspunkter. Det er her - og bare her - som man i Tidsskriftet kan lese om hva Legeforeningen mener.

Litteratur

1. Skriftlig spørsmål fra Jan-Henrik Fredriksen (FrP) til helse- og omsorgsministeren. Dokument nr. 15: 1009 (2012-2013). Innlevert: 14.3.2013. Sendt: 15.3.2013. Besvart: 22.3.2013 av helse- og omsorgsminister Jonas Gahr Støre. www.stortinget.no/no/Saker-og-publikasjoner/Sporsmal/

Skriftlige-sporsmal-og-svar/Skriftlig-sporsmal/?qid=56758 (21.5.2013).

2. Sundseth J, Berg-Johnsen J. Skaar-Holme S et al. Atlantoaksial rotasjonsfiksasjon - en årsak til torticollis. Tidsskr Nor Legeforen 2013; 133: 519-23.

3. Redaktørplakaten (28.2.2013). I: Store norske leksikon. http://snl.no/Redakt\%C3\%B8rplakaten (21.5.2013).

4. $\S 4-2$. Tidsskrift for Den norske legeforening. Den norske legeforenings lover. http://legeforeningen.no/Om-Legeforeningen/Organisasjonen/dnlf-lover/ den-norske-legeforenings-lover (21.5.2013).

5. LOV 2008-06-13 nr. 41: Lov om redaksjonell fridom i media. www.lovdata.no/all/ hl-20080613-041.html (21.5.2013).

6. Haug C. På vegne av hvem? Tidsskr Nor Lægeforen 2002; 122: 467.

7. Losvik OK. Forskning er ikke sannhet, men fortellinger. Tidsskr Nor Legeforen 2013; 133: 952-4.

8. Hem E. Medisin er debatt. Tidsskr Nor Legeforen 2012; 132: 1941 